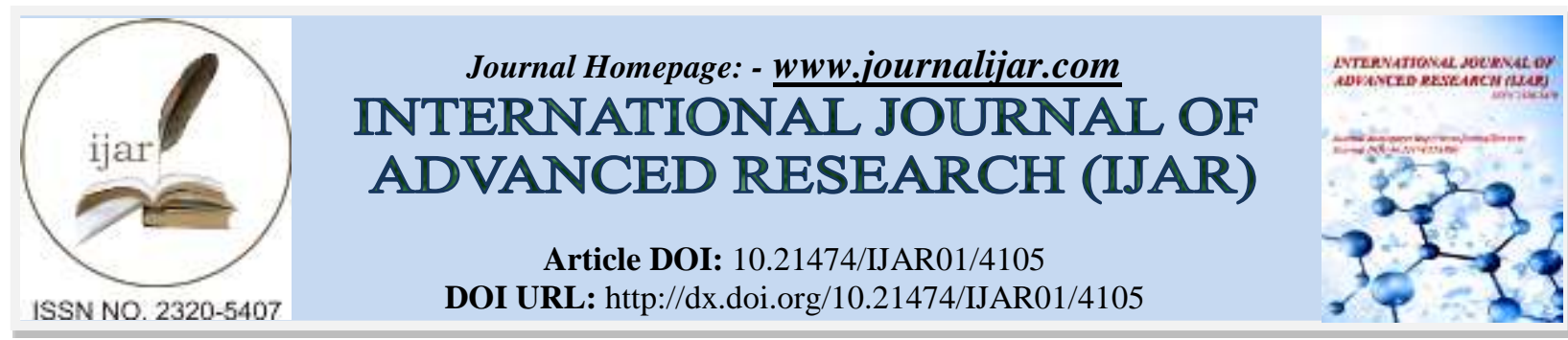

RESEARCH ARTICLE

\title{
THE USE OF ISLAMIC-BASED READING MATERIALS TO INCREASE READING COMPREHENSION ACHIEVEMENT: A STUDY AT ISLAMIC HIGHER EDUCATION INSTITUTION.
}

\author{
Muhsinin Muhsinin ${ }^{1}$, Mursid Saleh², Dwi Rukmini ${ }^{2}$ and Ahmad Sofwan ${ }^{2}$. \\ 1. Mataram State Islamic University, Indonesia. \\ 2. State University of Semarang, Indonesia.
}

\section{Manuscript Info}

Manuscript History

Received: 081 March 2017

Final Accepted: 13 April 2017

Published: May 2017

Key words:-

Islamic-based reading materials, Islamic education, reading comprehension, reading achievement

\begin{abstract}
This is an experimental research aimed at investigating the effects of using Islamic-based reading materials on the improvement of reading comprehension achievement of the students of Islamic Education Department, Mataram State Islamic University. For this purpose, 4 classes of 154 students were involved as the subjects of research. The students were divided into two groups - experimental and control groups. The experimental groups were taught using Islamic-based reading materials while the control groups were taught using non Islamic-based materials for one semester (14 meetings). At the end of the semester, comprehension reading tests were administered to the two groups of students. The results of the test indicated that the mean scores of the experimental group were higher than those of the control group. This difference was analyzed statistically using t-test to interpret the difference. The analysis revealed that the Sig. (2-tailed) was .021 which was smaller than the level of significance scores $.05(.012<.05)$. This statistically indicated that the different mean scores between the experimental and the control groups were the result of the different treatment given to the two groups. Thus, the use of Islamic-based reading materials influenced the reading comprehension achievement of the students.
\end{abstract}

Copy Right, IJAR, 2016,. All rights reserved.

\section{Introduction:-}

The idea of incorporating Islamic materials into the teaching of English at Islamic Education Institution is not new. Since the idea of Islamization of knowledge was proposed as the result of the first world conference of Muslim education in Mecca in 1977 many ELT practitioners from some Islamic countries have worked on this issue such as Anwarudin (2011) from Bangladesh, Shah et.al (2012) from Pakistan, Al-Haq and Al-Maseid (2009) from Jordan, etc. A research conducted by Shah et al (2012) about the contents of ELT textbooks and the relevance to learners' culture in Islamic context revealed that the book was developed without taking into consideration the needs, objectives, and attitudes of the learners. Some contents of the textbooks are too western oriented in terms of the themes, pictures, setting, and expressions used. This certainly is destructive to Islamic values and can influence the motivation of the learners.

In Indonesia there was Learning Assistance Program for Islamic Schools (LAPIS) and English Language Training for Islamic Schools (ELTIS) project in 2008 - 2010 funded by Australian government aimed at upgrading the 
English language capabilities of the students of Islamic secondary schools (Madrasah Tsanawiyah). One of the main programs was designing Islamic resource kits materials which enable the students to learn English using Islamic materials. This can be the starting point for ELT educators in Indonesia to develop ELT teaching materials using Islamic-based materials for students of all level of Islamic schools from elementary to tertiary education.

This research aimed at investigating the effectiveness of using Islamic-based reading material to improve reading comprehension achievement at Islamic tertiary education. The reading topics cover Islamic law (syari'ah), Islamic jurisprudence (fiqih), Islamic belief (aqidah), Islamic history, and Islamic education. There are some critical factors underlying this consideration. First, to filter the negative cultural effect of English as Western culture embedded in ELT course materials. Second, to provide students of Islamic education department opportunity to read Islamic materials written in English. Third, to increase the students' motivatation in reading the text because they have been familiar with the topics.

\section{Literature Review:- \\ Reading Comprehension:- Definition:-}

Snow (2002) defines reading comprehension as "the process of simultaneously extracting and constructing meaning through interaction and involvement with written language." Here, reading is perceived as an active process where the readers actively engaged in a process of extracting and constructing meaning from the text by making interaction and involvement with the text. The use of extracting and constructing in this definition means that the process of acquiring meaning involves not only the text but also something out of the text. Thus, reading comprehension is not a simple process but a complex process where the readers try to understand the meaning of the text by making use of information provided in the text and information from outside the text. This is in line with the idea proposed by Farrall (2012) that "... a full picture of reading comprehension does not emerge without consideration of both the text and the reader." Thus, understanding a text is considerably influenced by the reader. This can mean that different readers, with different background knowledge, can understand the same text differently.

The complexity of reading comprehension is also admitted by Klingner, Vaughn, and Boardman (2007). They claimed that reading comprehension is a "multicomponent, highly complex process that involves many interactions between readers and what they bring to the text (previous knowledge, strategy use) as well as variables related to the text itself (interest in text, understanding of text types)." This definition reveals that reading comprehension involves more than just the readers' responses to the text. It requires the ability of the readers to interact what they bring to the process as the readers such as the previous knowledge and strategies with what they have related to the text such as the interest in the text or the understanding of the text type. To be able to do the process successfully, the readers need to know the variables that they have to bring to the process and know how to activate them during the process. The failure to identify and identify them will result in incapability to comprehend the reading text.

Guthrie and Scafiddi (2004) offers another formulation of definition for reading comprehension. They suggest that "reading comprehension consists of the processes of constructing conceptual knowledge from a text through cognitive interaction and motivational involvement with the text." Here, again, reading is perceived as an active and complex process. It involves cognitive and motivation of the readers to read the text. According to this definition the ability to grasp the meaning from the text depends highly on the cognitive knowledge that the readers have related to the text and the motivation they have in reading the text.

\section{Factors Affecting Reading Comprehension:-}

So complicated is the reading process that there are some factors considered to be responsible for the failure of the comprehension. This happens not only with the reading in the first language but also with the second and foreign language. As for the second and foreign language reading, lack of vocabulary and grammatical knowledge are considered to be the two most responsible factors for the comprehension failure. Mikulecky and Jeffries (2007) state that good reading comprehension depends on understanding the words you are reading. The more words you recognize and understand in a text, the better your comprehension will be. However, knowing the words only is not enough. Laufer \& Sim, (1985) mention other important elements contributing to comprehensions such as the knowledge of the subject matter, discourse marker, and syntactic structure. These elements will highly influence the ability of a reader to comprehend a text. 
Torgesen (2008) also identifies several factors that influence proficient comprehension such as the ability to identify symbols, range of lexical knowledge, general knowledge, the ability to apply appropriate reading strategies, knowledge of the text types, the reasoning and inferential skills, and interest in reading. These clarify that to come to full understanding of a text a reader should have proficient knowledge and be able to apply the knowledge appropriately during the reading.

However, there are also some barriers that prevent the reader form understanding the text which the reader should be able to avoid. Field (2006) reveals some factors that can be the barriers to reading comprehension such as the language, appropriateness of materials, and language environment. This means that a reader who still has problems with the language (the vocabulary and the grammar) will find it hard to comprehend a text in that particular language. The same thing happens to a reader who knows very little about the materials. He/she will experience difficulties in comprehending the text. Field also uncovers that reading in the first, second or foreign language will create different level of difficulties. Reading in the foreign language will be more difficult due to the problems of language that the reader has.

\section{Approaches to the Teaching and Learning of Reading:-}

The approaches of teaching and learning reading discussed here focus on the ability to comprehend second or third language reading text in line with the subject of the research that is the university students learning English as a foreign language. Therefore, the three basic teaching or learning approaches in reading proposed by Sadoski (2004) which include program-controlled teaching/learning, teacher-controlled teaching/learning, and reader-controlled teaching/learning are the most appropriate approaches to be discussed further.

Program-controlled teaching/learning according to Sadoski (2004) is characterized by the domination of the program over the teacher and the readers. Teachers and readers are subordinate where they have to work together to follow the structure of lessons and activities which have been planned externally. However, teachers still have to help the readers/learners to understand the reading text. The example of this approach is when the teachers do not provide their teaching materials but have to use the reading text from the course book.

The other criterion of this approach is the division of reading skills into a set of skills which is taught separately: 'decoding, comprehension, and response' (Sadoski, 2004:82). Decoding is divided into a set of skills such as phonic skills, sight vocabulary skills, context skills, and dictionary or reference skills. Comprehension consists of literal comprehension skills, inferential or interpretive comprehension skills. Response includes critical, applied, or appreciative skills.

Sadoski (2004) further explains that each of these skills needs to be taught comprehensively to help the readers/learners develop these skills. For example, to develop decoding skill teachers are suggested to help the readers/learners to learn consonant and vowel sounds and phonic generalization for their combination, learn common morphemes and syllable divisions, learn high-frequency words by sight, learn to use various kinds of context clues. This clearly indicates that reading should be taught and cannot be developed just by asking the students to read by themselves.

Unlike the previous approach where the teacher is less dominant, in this approach, teacher is dominant and the readers/learners and the program are subordinate. The teacher provides his own teaching materials based on his own teaching knowledge, experience and judgment. In other words, this approach makes the teacher in total control of the program which enables him to make his own decision related to the process of teaching and learning. However, often time, experienced teacher will avoid being too authoritative by considering the need of the learners and use methods that involve them in a student-centered activity. This approach is in line with the idea proposed by Harmer (2004) who perceives the role of a teacher as designer of learning materials. This means that the teacher has to design his own materials for the teaching of reading.

Reader-controlled teaching and learning approach puts the readers or learners in a dominant position over the teacher and the program. This enables them to play an active role in the learning or teaching process and not just as a 'passive perceptual process'(Uso-Juan \& Martinez-Flor, 2006) that consider them as passive recipients of the message expressed by the writers through the text. However, this does not mean that the teachers are not needed anymore. They are still needed but the readers or learners have opportunity to provide their own direction in reading. This approach enables the readers or learners to develop their reading skills by using them directly in their own 
reading. This, consequently develops them become independent readers who decide their own reading materials and objectives. Therefore, this type of approach is very suitable for advanced readers or learners who read individually by selecting the materials under the guidance of the teacher based on their own interest, level and ability.

\section{English and Culture:-}

Language and culture cannot be separated because they are interrelated to each other. A language is believed to be the representation of a culture. This is in line with the idea proposed by Byram (1991) who claimed that 'language is not simply a reflector of an objective cultural reality. It is an integral part of that reality through which other parts are shaped and interpreted.' Similarly, Thanasoulas (2001) more directly emphasizes that a language does not exist apart from culture. This certainly makes it impossible to see a language without looking at the culture as the producer of the language. Wardhaugh (2002) even claims that the structure of a language determines the way in which speakers of that language view the world.

The implication of the inseparable relationship between language and culture certainly influences second and foreign language learning and teaching. This can mean that when someone learns a new language, he/she has to learn the culture of the language inevitably. Therefore, learning a new language implicates the learning of a new culture (Allwright \& Bailey 1991). As a consequence, a language teacher is also a teacher of a culture (Byram 1989).

The idea that a the teaching of language is also influenced by the culture of the target language is also supported by other experts such as Valdes (1986) who believes that to teach a language without teaching the cultural contents is impossible and Kramsch (1993) who claims that teaching a language means teaching its culture. The importance of culture in the teaching and learning of a language can be seen in the ability to use the language. The knowledge of culture determines the ability to use the learned language. (Martinez-Flor \& Uso-Juan, 2006) admit this and put intercultural competence as one of the competences in communicative competence. This implicitly means that the cultural knowledge of the target language is the same importance as the other language competences such as grammatical competence, discourse competence, pragmatic competence, and strategic competence.

The fact that learning a language means learning a new culture can cause suspicious among language learners and educators. Anwaruddin (2011) in commenting the four dimensional approach of liaison between globalization, empire, and TESOL proposed by Kumaravadivelu (2003) says that cultural dimension refers to the spread of English culture worldwide as the effect of the teaching of English. He even suspects that the use of certain approaches and methods in TESOL which require the learners to think like English-native speakers is the way to promote English culture especially the U.S. and the U.K.

Anwaruddin (2011) also claims that another form of cultural dimension in the teaching of English is the use of English language teaching to support missionary. Since the start of missionary work, English language teaching has long been associated with Christianity. Snow (2001) stated in his book English Teaching as a Christian Mission: An Applied Theology that teaching English is an act of Christian service and should be seen as a mission itself. Consequently, Christian English teachers are being sent as missionaries all over the world to teach English.

The fact that English language teaching is a means of spreading Christianity has been responded by some Moslem ELT professionals in the Middle East by establishing TESOL Islamia. Kumaravadivelu (2006) mentions that the main mission of the organization is to adjust the ELT teaching and learning with the sociopolitical, sociocultural, and socioeconomic interests of the Islamic world. They also intend to promote and defend Islamic values in the teaching of English as a second or foreign language in the Muslim World. This means that TESOL Islamia wants to preserve Islamic values and culture from the infiltration of Western culture through English language learning and teaching. One of the ways to do it is by using Islamic-based materials to teach English.

Some ELT educators have proposed the need to use Islamic-based materials in teaching English for Muslim students to avoid the negative influence of Western culture such as Asraf (1997), Rohmah (2012), and Mclennan (2013). They claim that the use of English teaching materials containing western culture, values and norms can lead to resistance among the Moslem students. Consequently, this can influence their motivation in learning. For this reason, Islamic students should learn English using Islamic-based materials to increase the motivation and avoid the resistance. By using Islamic-based materials the students can learn English and at the same time develop their knowledge about Islamic teaching. 


\section{Methods:-}

The Subjects:-

The subjects of this research were the four classes of the third semester students of Islamic Education Department of Mataram State Islamic Institute (IAIN Mataram). Two classes (III A and III B) were assigned as the experimental group and the other two classes (III C and III D) as the control group. These groups of students were assumed to have the same level of English knowledge because the distribution of students into different classes was based on the students' identification numbers. Table 1 below shows the distribution of the subjects as the experimental and the control groups.

Table 1:- Subjects of the research.

\begin{tabular}{|c|c|c|c|c|}
\hline \multirow{2}{*}{ No } & \multicolumn{2}{|c|}{ Control Group } & \multicolumn{2}{c|}{ Experimental Group } \\
\cline { 2 - 5 } & Class & Number of Students & Class & Number of Students \\
\hline 1 & III C & 39 & III A & 38 \\
\hline 2 & III D & 39 & III B & 38 \\
\hline \multicolumn{2}{|c|}{ Total } & 78 & Total & 76 \\
\hline
\end{tabular}

\section{Place and Time of Research:-}

This research was conducted at Islamic Education Department, Faculty of Education and Teacher Training, Mataram State Islamic Institute (IAIN Mataram) in the first semester of academic years 2015/2016.

\section{The Procedures:-}

The classes were divided into two groups: class III A and class III B as the experimental groups and class III C and class III D as the control groups. The experimental groups were taught using Islamic-based reading materials and the control groups were taught using non Islamic-based reading materials. They were taught for one semester and at the end of the semester a reading comprehension test was administered for both groups. The results of the test were analyzed to see the different reading comprehension achievement of the two groups.

\section{Technique of data Collection:-}

The technique used to collect data was test. It was in the form of reading comprehension test with 25 comprehension questions. There were five short reading texts followed by 5 questions for each text. Two texts were multiple choice forms and the other three were true/false, completion, and essay. The test was administered to find out the reading scores of both the experimental and control groups. Before the test was used to collect data, it was tried out first to see the validity and reliability of the test.

\section{Technique of data Analysis:-}

The technique used to analyze the data which were in the forms of scores as the result of the test was t-test. This was done to see the effect of the different learning materials given to the students' learning outcomes. The result of the test was analyzed using Bivariate Correlation Test. Because the application of t-test required the normality and homogeneity of the scores distribution, prior to the use of t-test, other statistical analyses were conducted: One Way Anova and Shapiro-Wilk Normality Test. One Way Anova was used to see the homogeneity of the scores distribution, and Shapiro-Wilk Normality Test was used to see the normality of the scores distribution.

Before the test was used to collect data, it was tried out first to see the validity and reliability of the test. The try out was conducted to 15 students of IED, Faculty of Education and Teacher Training, Mataram State Islamic Institute (IAIN Mataram). The item validity test using SPSS 22 was conducted to see the validity of the individual item test used. The results showed that all of the r-item scores were higher than the r-table (.388) which statistically means that the test was considered to be valid. As for the reliability test, the Alpha Cronbach's Test was conducted to see the reliability of the multiple choice and essay test. The result of the analysis proved that the values of Alpha Cronbach's for both the multiple choice and essay test were higher than the value of r-table which statistically indicated that the test was considered to be reliable.

\section{Results:-}

The test scores results of the students in the experimental group and the control group are presented in Table 2 below. 
Table 2:- Test scores Results.

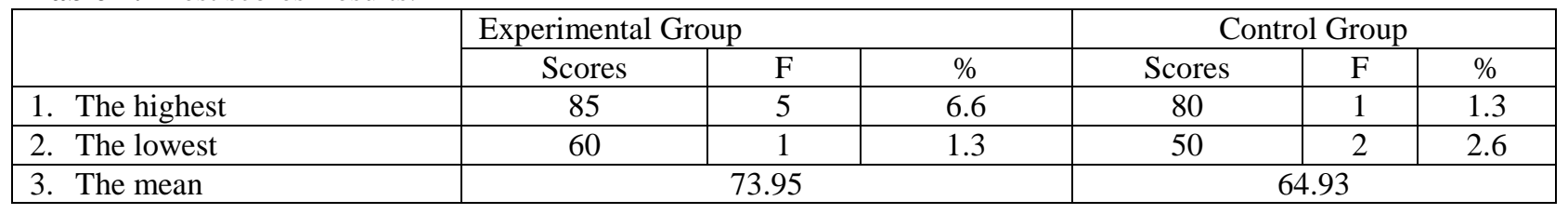

Table 2 shows that the highest score for the experimental group was 85 and for the control group 80 . The percentage of students obtained the highest score for the experimental group was 6.6\% (5 students) while for the control group was $1.3 \%$ (1 student). The lowest score for the experimental group was 60 and 50 for the control group. The percentage of the students who got the lowest score for the experimental group was $1.3 \%$ (1 student) and for the control group was $2.6 \%$ ( 2 students). The mean score for the experimental group was 73.95 and for the control group 64.93. It can be interpreted from the table that the students in the experimental group performed better in their reading comprehension test compared to the students in the control group.

Table 3:- Range of the scores Results.

\begin{tabular}{|c|c|c|c|c|c|}
\hline \multirow{2}{*}{ No } & \multirow{2}{*}{ Range of Scores } & \multicolumn{2}{|c|}{ Experimental Group } & \multicolumn{2}{c|}{ Control Group } \\
\cline { 2 - 5 } & & F & $\%$ & F & $\%$ \\
\hline 1 & $50-55$ & - & - & 12 & 15.4 \\
\hline 2 & $56-60$ & 1 & 1.3 & 22 & 28.2 \\
\hline 3 & $61-65$ & 8 & 10.5 & 22 & 28.2 \\
\hline 4 & $66-70$ & 30 & 39.5 & 13 & 16.7 \\
\hline 5 & $71-75$ & 22 & 28.9 & 8 & 10.2 \\
\hline 6 & $76-80$ & 10 & 13.1 & 1 & 1.3 \\
\hline 7 & $81-85$ & 5 & 6.6 & - & - \\
\hline 8 & $86-90$ & - & - & - & - \\
\hline
\end{tabular}

The table shows the distribution of scores results of the students from the experimental group and the control group. From the table, majority of the students in the experimental group got the score $70(39.5 \%)$, followed by $75(28.9 \%)$, and $80(13.1 \%)$. For the control group, majority of the students got $60(28.2 \%)$ and $65(28.2 \%)$, followed by 70 (16.7\%). $88.2 \%$ of the students in the experimental group got the range of scores between 70 to 85 , and $11.8 \%$ of the students got the scores below 70 . For the same range of scores, $28.2 \%$ of the students in the control group got 70 and above and the rest $71.8 \%$ got the scores below 70 . If 60 is the passing grade, there will be $15.4 \%$ of the students (12) in the control group who fail the course and all students in the experimental group pass the course.

\section{Discussion:-}

Prior to the analysis of the test scores using t-test, test of homogeneity and normality should be done first because the distribution of scores should be homogenous and normal before they can be analyzed using t-test. Based on the result of the test of homogeneity the scores obtained was .179 which was higher than the level of significance score $.05(.179>.05)$. This statistically indicated that the distribution of scores was homogenous. (See Table 4).

Table 4:- Result of homogeneity test.

\begin{tabular}{|c|c|c|c|}
\hline scores & \multicolumn{3}{l|}{} \\
\hline Levene Statistic & df1 & df2 & Sig. \\
\hline 1.821 & 1 & 152 & .179 \\
\hline
\end{tabular}

The result of the normality test of the distribution of the scores obtained from the two groups (experimental and control) proved that the distribution of the scores was normal because the scores for groups A and B was higher than the scores of level of significance $.05(.312>.05, .203>.05)$. (See Table 5).

Table 5:- Result of Normality test.

\begin{tabular}{|c|c|c|c|c|c|c|c|}
\hline \multirow{2}{*}{} & \multirow{2}{*}{ Groups } & \multicolumn{3}{|c|}{ Kolmogorov-Smirnov $^{\text {a }}$} & \multicolumn{3}{c|}{ Shapiro-Wilk } \\
\cline { 3 - 8 } & & Statistic & Df & Sig. & Statistic & Df & Sig. \\
\hline \multirow{2}{*}{ Scores } & group A & .879 & 78 & .211 & .944 & 78 & .312 \\
\cline { 2 - 9 } & group B & .821 & 76 & .136 & .914 & 76 & .203 \\
\hline
\end{tabular}


After the distribution of scores was homogenous and normal, the t-test analysis was done using SPSS 22 . The result of the analysis is presented in table 6.

Table 6:- Statistical analysis of the test results

\begin{tabular}{|l|l|l|l|l|l|l|}
\hline \multicolumn{2}{|c|}{} & \multicolumn{2}{l|}{$\begin{array}{l}\text { Levene's Test for Equality } \\
\text { of Variances }\end{array}$} & \multicolumn{2}{l|}{ t-test for Equality of Means } \\
\cline { 3 - 7 } & F & Sig. & T & Df & Sig. (2-tailed) \\
\hline \multirow{2}{*}{ Scores } & $\begin{array}{l}\text { Equal variances } \\
\text { assumed }\end{array}$ & 1.821 & .179 & 7.341 & 152 & .021 \\
\cline { 2 - 7 } & $\begin{array}{l}\text { Equal variances not } \\
\text { assumed }\end{array}$ & & & 6.582 & 148.676 & .011 \\
\hline
\end{tabular}

The output table shown that the Sig. (2-tailed) is .021 which is smaller than the level of significance scores .05 (.012 $<.05)$. This statistically indicates that there is a different means between the test scores result between experimental and control groups. This also means that the different learning outcomes between the groups were the result of the different treatment given to the two groups. Thus, the use of Islamic-based reading materials significantly increases the reading comprehension achievement of the experimental groups.

\section{Conclusions:-}

The research found out that the test scores of the experimental group were higher than the scores of the control group. This indicated that the students who were taught using Islamic-based reading materials performed better in reading comprehension achievement compared to the students who were not taught using Islamic-based reading materials. Therefore, it is recommended that Islamic-based reading material be used to teach reading to Islamic Department students of Islamic Higher Education institution. There are several advantages of using Islamic-based reading materials for teaching reading to students of Islamic Education Department. First, it can filter the negative cultural effect of English as Western culture embedded in ELT course materials. Second, to provide opportunity for students of Islamic education department to read Islamic materials written in English. Third, to increase the students' motivation in reading the text because they have been familiar with the topics or they have already got the background knowledge of the topics which are part of their subjects such as Islamic law (syari'ah), Islamic jurisprudence (fiqih), Islamic belief (aqidah), Islamic history, and Islamic education. Lastly, the materials are authentic materials which is very important to introduce the learners with the real use of English language outside the classroom. As proposed by Berardo (2006) that the use of authentic materials in the classroom is to "expose" the learner to as much real language as possible. Even if the classroom is not a "real-life" situation, authentic materials do have a very important place within it. In this research, the reading materials are taken from authentic Islamic resources such as books and journal articles written in English.

\section{References:-}

1. Al-Haq, F. A. \& Al-Masaeid, A. L. (2009). Islam and Language Planning in the Arab World: A Case Study in Jordan. Iranian Journal of Language Studies (IJLS). 3(3): 267-302.

2. Allwright, D. and Bailey, K. M. (1991). Focus on the Language Learner. Cambridge: Cambridge University Press.

3. Anwaruddin, S.M. (2011). Hidden Agenda in TESOL Methods. Journal of English as an International Language. 6(1): $47-58$.

4. Ashraf, R. M. (1997). The Cultural Implications of Teaching English as a Second or Foreign Language. Muslim Education Quarterly. 14(4): 4-19.

5. Berardo, S.A. 2006. The Use of Authentic Materials in the Teaching of Reading. The Reading Matrix. 6(2): 60-69.

6. Byram, M. (1991). Teaching culture and language: towards an integrated model. In Buttjes, D. and Byram, M. (eds.) Mediating languages and cultures: towards an intercultural theory of foreign language education. Clevedon. Multilingual Matters. 17-30.

7. Farrall, M.L. (2012). Reading Assessment Linking Language, Literacy, and Cognition. New Jersey: John Wiley \& Sons, Inc.

8. Guthrie, J. T., \& Scafiddi, N. T. (2004). Reading comprehension for information text: Theoretical meanings, developmental patterns, and benchmarks for instruction. In J. T. Guthrie, A. Wigfield, \& K. C. Perencevich 
(Eds.), Motivating reading comprehension: Concept Oriented Reading Instruction (pp. 225-248). Mahwah, NJ: Erlbaum.

9. Harmer, J. (1991). The Practice of English Language Teaching. London and New York: Longman.

10. Klingner, J.K., Vaughn, S., and Boardman, A. (2007). Teaching Reading Comprehension to Students with Learning Difficulties. New York: The Guilford Press.

11. Kumaravadivelu, B. (2006). Dangerous Liason: Globalization, Empire and TESOL. In Edge, J. (ed.). (re-) Locating TESOL in an Age of Empire. New York: Palgrave Macmillan.

12. Laufer, B. \& Sim, D.D. (1985). Measuring and Explaining the Reading Treshold Needed for English for Academic Purposes Texts. In Foreign Language Annals. 18(5): 405-411.

13. Mikulecky, B.S, \& Jeffries, L. (2007). Advanced Reading Power. New York USA: Pearson Longman.

14. Sadoski, M. (2004). Conceptual Foundations of Teaching Reading. New York: The Guilford Press.

15. Shah, S.K., Afsar, A., Haq, H.M.F., \& Khan, Z.A. (2012). Course Contents of English Language Textbooks and their Relevance to Learners' Culture in an Islamic Context. Journal of Education and Practice. 3(12): 165180 .

16. Thanasoulas, D. (2001). Radical Pedagogy: The importance of teaching culture in the foreign language classroom. Retrieved October 3, 2005 from the International Consortium for the Advancement of Academic Publication Web site: http://radicalpedagogy.icaap.org/content/ issue3_3/7-thanasoulas.html

17. Uso-Juan, E \& Martinez-Flor, A. (eds). (2006). Current Trends in the Development and Teaching of the Four Language Skills. Berlin: Mouton de Gruyter.

18. Valdes J.M. (1986). Culture Bound: Bridging the Cultural Gap in Language Teaching. Cambridge: Cambridge University Press.

19. Wardhaugh, R. (2002). An Introduction to Sociolinguistics (Fourth Ed.). Oxford: Blackwell Publishers. 